\title{
CENTRAL NERVOUS SYSTEM PARACOCCIDIOIDOMYCOSIS. REPORT OF A CASE SUCCESSFULLY TREATED WITH ITRACONAZOL
}

\author{
Luis A. VILLA(1), Angela TOBÓn(2), Antonio RESTREPO(3), Daniel CALLE(4), David S. ROSERO(4), Beatriz L. GÓMEZ(2) \& Angela RESTREPO(2)
}

\begin{abstract}
SUMMARY
Paracoccidioidomycosis (PCM) is a primary pulmonary infection that often disseminates to other organs and systems. Involvement of the central nervous system (CNS) is rare and due to the fact that both clinical alertness and establishment of the diagnosis are delayed, the disease progresses causing serious problems. We report here a case of neuroparacoccidioidomycosis (NPCM), observed in a 55 year-old male, who consulted due to neurological symptoms (left hemiparesis, paresthesias, right palpebral ptosis, headache, vomiting and tonic clonic seizures) of a month duration. Upon physical examination, an ulcerated granulomatous lesion was observed in the abdomen. To confirm the diagnosis a stereotactic biopsy was taken; additionally, mycological tests from the ulcerated lesion and a bronchoalveolar lavage were performed. In the latter specimens, $P$. brasiliensis yeast cells were visualized and later on, the brain biopsy revealed the presence of the fungus. Treatment with itraconazole (ITZ) was initiated but clinical improvement was unremarkable; due to the fact that the patient was taking sodium valproate for seizure control, drug interactions were suspected and confirmed by absence of ITZ plasma levels. The latter medication was changed to clonazepam and after several weeks, clinical improvement began to be noticed and was accompanied by diminishing P. brasiliensis antigen and antibody titers. In the PCM endemic areas, CNS involvement should be considered more often and the efficacy of itraconazole therapy should also be taken into consideration.
\end{abstract}

KEYWORDS: Paracoccidioidomycosis; Central nervous system; Itraconazole

\section{INTRODUCTION}

Paracoccidioidomycosis (PCM), a mycosis caused by the dimorphic fungus Paracoccidioides brasiliensis, is a systemic disease that afflicts predominantly rural adult males living in the endemic countries of South and Central America. The primary lesion occurs in the lungs ${ }^{13}$ but often disseminates to other organ and systems, notably the oral mucosa, the adrenal glands, the reticulo-endothelial system, the skin, and less frequently to other organs such as the central nervous system (CNS). According to AJELLO ${ }^{1}$, the latter manifestation was initially described by Pereira and Jacobs in 1919.

In neuroparacoccidioidomycosis (NPCM), as well as in other more common forms of the mycosis, patients are predominantly males, age 30-50 years. The CNS manifestations may become apparent in the meninges or in the cerebral parenchyma where they give rise to the corresponding clinical manifestations, including those of a pseudotumoral lesion ${ }^{9,10,14-16,18-20 . ~}$

The diagnosis of NPCM is difficult to establish. Neuroimaging studies such as Computerized Tomography (CT) and Magnetic Resonance Imaging (MRI) are helpful in suggesting the disease but they do not furnish a definitive diagnosis ${ }^{8,17}$. The latter is obtained only when the fungus is observed microscopically or isolated from biopsies or from the cerebrospinal fluid $(\mathrm{CSF})^{6,14}$. However, the latter sample, is not too effective as repeated specimens, large quantities of and prolonged incubation of the cultures are required ${ }^{\mathbf{1 6}}$. Consequently, invasive procedures are often needed to obtain representative samples for diagnosis.

Detection of $P$. brasiliensis may be improved by immunologic testing for antibodies, such as the agar gel immunodiffusion and the complement fixation ${ }^{6,11,14}$, and more recently, also by antigen detection procedures ${ }^{11}$.

Amphotericin B, administered either by the intravenous or the intrathecal routes, has been used in the treatment of NPCM. When the dose has been completed, treatment is followed with sulfonamides for chronic supportive therapy ${ }^{2,9,10,14,20}$. Certain sulfonamide-trimethoprim combinations, such as cotrimoxazol and cotrimazine, have also been used due to the high drug levels attained in the $\mathrm{CSF}^{3}$. Surgery is reserved for patients in whom granulomas are accessible and the symptoms have failed to improve with specific therapy ${ }^{14}$. We present here the record of a Colombian patient with NPCM whose symptoms and neurological signs improved or resolved during therapy with itraconazole.

(1) Departamento de Neurología, Facultad de Medicina, Universidad de Antioquia y Hospital Universitario San Vicente de Paúl.

(2) Unidad de Micología Médica, Corporación para Investigaciones Biológicas (CIB), Medellin, Colombia.

(3) Departamento de Medicina Interna, Instituto de los Seguros Sociales (ISS).

(4) Facultad de Medicina, Universidad Pontificia Bolivariana, Medellín, Colombia.

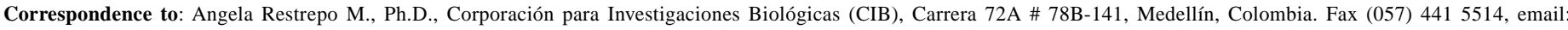
angelares@epm.net.co 


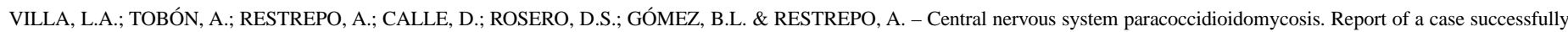
treated with itraconazol. Rev. Inst. Med. trop. S. Paulo, 42(4): 231-234, 2000.

\section{CASE REPORT}

The patient was a 55 year-old male patient, car driver in the city of Medellín but who in his younger years, was a farmer in a rural region. He ingested alcohol regularly and has been a heavy cigarette smoker (35 packets/year). He attended the Social Security Hospital because for the last month, he had been experiencing a progressive problem characterized by left hemiplegia, accompanied by paresthesias and right palpebral ptosis. For the last three days, he has also experienced tonic-clonic seizures of the left extremities with secondary generalization, global headache and persistent vomiting.

Physical signs showed that the patient was alert and cooperative. Additionally, his vital signs were within normal limits. A non-painful cutaneous ulceration, $3 \mathrm{X} 2$ centimeters, was observed in the abdomen in the periumbilical zone; it had raised borders and a granulomatous appearance. This lesion was first noticed a year ago but the patient disregarded it, as it caused no major discomfort.

Neurological examination disclosed that the patient was conscious, had a highly preserved cortical function and his memory was also normal.

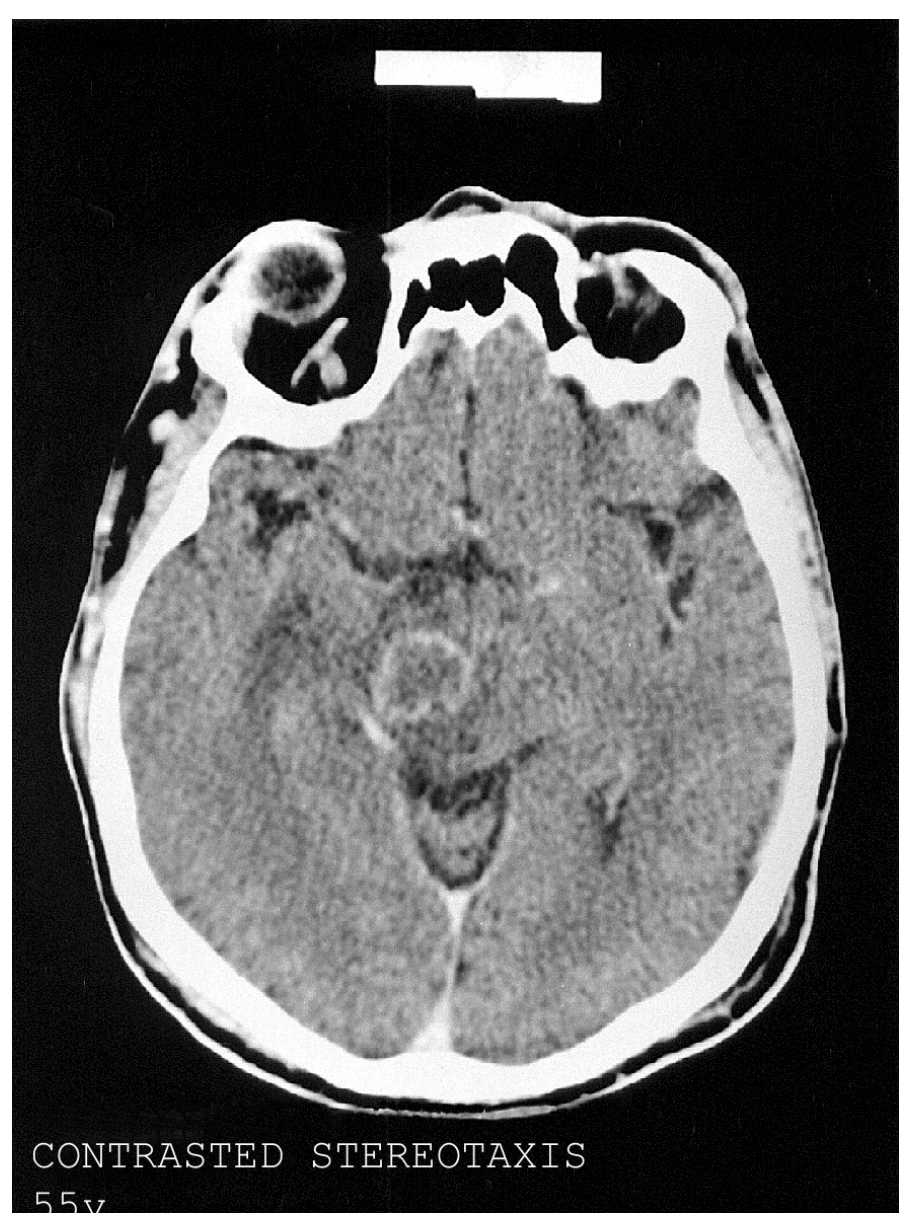

Fig. 1 - CT brain scan at diagnosis showing a ring-enhancing lesion in the right mesencephalon with mass effect and peri-lesional edema.
There were no signs of meningeal irritation; the ocular funduscopic examination revealed that there was venous congestion with papilledema. The pupillae were isochoric and normoreactive; common ocular motor nerve palsy was noticed. There was central right facial paresia and left hypoesthesia and hemiparesis (in a scale of 0-5, the muscle strength was 4/4 in all segments of the left hemibody). Pathological reflexes (Hoffman, Babinski) were absent. Simple and contrasted CNS CT scans, thoracic $\mathrm{X}$-rays as well as laboratory tests were ordered.

At the level of the right thalamus, CT scans revealed a ring-enhancing lesion accompanied by a large area of peri-lesional edema (Fig. 1). A representative biopsy was then taken and the new $\mathrm{CT}$ indicated that the lesion involved not only the right thalamus but also the mesencephalon; it measured $18 \times 16 \mathrm{~mm}$ and had a necrotic center. The thoracic X-rays showed bilateral interstitial infiltrates in both basal fields. Diagnostic impressions comprised toxoplasmosis, lymphoma, tuberculosis and astrocytoma. A stereotaxic biopsy was carried out with the aid of a CT scan and reported, later on, as compatible with cryptococcosis, a diagnosis that prompted fluconazole treatment.

The blood biochemical parameters and the hematological tests were normal with the exception of leukocytosis $\left(22,900 / \mathrm{mm}^{3}\right)$ and neutrophilia $\left(19,150 / \mathrm{mm}^{3}\right)$. Sedimentation rate was $35 \mathrm{~mm}$ and the $C$ reactive protein was $1.44 \mathrm{mg} / \mathrm{dL}$. Tests for HIV and toxoplasmosis ( $\operatorname{IgM})$ were negative. Repeated searching for AFB in sputum (3 samples) also gave negative results.

Three weeks later and due to lack of response, the initial diagnosis was questioned and mycological studies such as direct $\mathrm{KOH}$ examination and cultures were ordered. These included specimens from the abdominal ulcer as well as a brochoalveolar lavage (BAL). Serum and CSF were also subjected to immunological testing for antibody (agar gel immunodiffusion and complement fixation) and antigen detection (inhibition ELISA). Additionally, authorization to revise the brain biopsy slides was solicited.

Direct examination of both clinical specimens revealed the presence of $P$. brasiliensis multiple budding yeast cells. The latter were also observed in the H\&E-stained brain tissue; a few days later, the immunological tests revealed the presence of antibodies against the fungus, as well high levels of circulating antigen. Consequently, the diagnosis of PCM became firmly established.

Treatment with itraconazole (ITZ), $400 \mathrm{mg} /$ day, was initiated. The patient had been receiving sodium valproate $(400 \mathrm{mg} /$ day in the morning and $200 \mathrm{mg} /$ day in the evening) to avoid seizures. One month after antifungal therapy, clinical response was minimal; consequently, ITZ plasma levels were determined and found that they were undetectable. At this time, sodium valproate was suspended and replaced by clonazepam, 1mg/day; ITZ continued to be administered at the same dose (Table 1).

Fifteen days later, ITZ plasma levels have attained acceptable levels $(4.60 \mu \mathrm{g} / \mathrm{mL})$, and as a consequence, the ITZ dose was lowered to 300 $\mathrm{mg}$ /day. During the first two months at this dose, the abdominal ulceration and the common ocular motor nerve palsy healed; the headache diminished and disappeared on prolonged therapy ( 7 months). The hemiparesis became less noticeable but persisted as sequelae. 


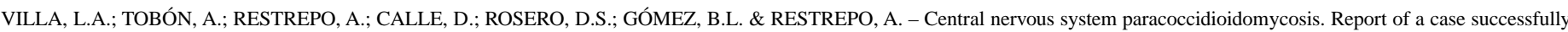
treated with itraconazol. Rev. Inst. Med. trop. S. Paulo, 42(4): 231-234, 2000.

After 5 months of therapy, ITZ levels were sufficiently high (9.76 $\mu \mathrm{g} / \mathrm{mL}$ ) to allow a decrease in the dose (200 mg/day); the latter was maintained until completing a year of therapy (Table 1). Laboratory tests failed to reveal drug toxicity. Periodically, control tests to determine the presence of both antibodies and circulating antigens, were done. Antigen titers diminished after correction for the anti-seizure medication and became undetectable 5 months after suspending the ITZ-sodium valproate combination.

At time of this report, the patient has been followed for 2 years without experiencing clinical or mycological relapses. A CT scan taken six months after the end of treatment, revealed substantial improvement, as shown in Fig. 2.

\section{DISCUSSION}

In countries where PCM is endemic, the neurological manifestations of this disorder should be taken into consideration in undiagnosed patients with signs and symptoms of chronic meningoencephalitis or expansive CNS processes. According to autopsy studies, NPCM occurs more often than suspected by the physician and consequently, treatment is delayed and death may ensue ${ }^{15,19}$.

CNS involvement represents dissemination from the primary pulmonary focus which is often a silent process; when other extrapulmonary lesions are present in the patient, diagnosis becomes simpler as samples for laboratory examination are easier to obtain. PLÁ et al. ${ }^{16}$ revised 22 NPCM cases and found that most patients had lesions outside the brain, mostly in the lungs (13/17 cases with $\mathrm{X}$-rays films), the teguments ( 8 cases) and the lymph nodes ( 1 case). These results reveal the disseminated pattern of this mycosis s, $10,14,16_{\text {. }}$

In the patient reported here, there were indications of previous lung involvement and also, presence of a cutaneous lesion that should have led to suspect a multisystemic disorder. Nonetheless, this important lesion was disregarded.

The clinical manifestations of the CNS in PCM are those of a chronic meningitis or of an expansive tumor-like lesion (paracoccidioidoma) $)^{9,10,14}$. Histologically, the latter is characterized by granulomas that may be localized anywhere within the CNS, especially in areas with adequate blood supply, such as the cerebral hemispheres, the cerebellum and more rarely, the thalamus, the medulla and the spinal cord ${ }^{15,19}$. Involvement of the thalamus such as was observed in our patient, was recorded in only two of the 22 cases revised by PLÁ et al. ${ }^{16}$.

Treatment of NPCM has relied on amphotericin B, an effective medication known to be nephrotoxic and capable of producing systemic effects $^{4}$. Several authors consider that sulfonamides by their capacity to penetrate into the brain, are the drugs of choice. Nonetheless, prolonged periods of continuous treatment (3-5 years) are required before adequate results can be obtained ${ }^{3,10,14,20}$. The azole derivatives ketoconazole, fluconazole and itraconazole have all been used for the treatment of non-meningeal forms of PCM. Itraconazol is considered by our group as the choice medication in other forms of $\mathrm{PCM}^{12,13}$ and although it does not attain adequate CNS levels, this drug concentrates in the tissues ${ }^{14}$. Nonetheless, the adequacy of its use in CNS disease has not been definitively demonstrated.
Table 1

Itraconazole plasma levels and laboratory findings: influence of concomitant sodium valproate treatment

\begin{tabular}{ccccc}
\hline Month & $\begin{array}{c}\text { Itraconazol } \\
\text { levels } * \\
(\mu \mathrm{g} / \mathrm{mL})\end{array}$ & $\begin{array}{c}\text { Complement } \\
\text { fixation }\end{array}$ & $\begin{array}{c}\text { P. brasiliensis } \\
\text { antigen titers } \\
(\mu \mathrm{g} / \mathrm{mL})\end{array}$ & $\begin{array}{c}\text { Concommitant } \\
\text { therapy } \\
\text { Itraconazol/ } \\
\text { Valproato/ } \\
\text { Clonazepam } \\
(\mathrm{mg} / \mathrm{day})\end{array}$ \\
\hline 1 & Not detectable & $1: 64$ & 11 & $400 / 500 / 0$ \\
2 & 4.60 & $1: 64$ & 19 & $400 / 0 / 1$ \\
5 & 9.76 & $1: 16$ & 15 & $300 / 0 / 1$ \\
7 & 4.60 & $1: 8$ & 0 & $200 / 0 / 1$ \\
\hline
\end{tabular}

* Therapeutic failures are associated with levels $<2 \mu \mathrm{g} / \mathrm{mL}$

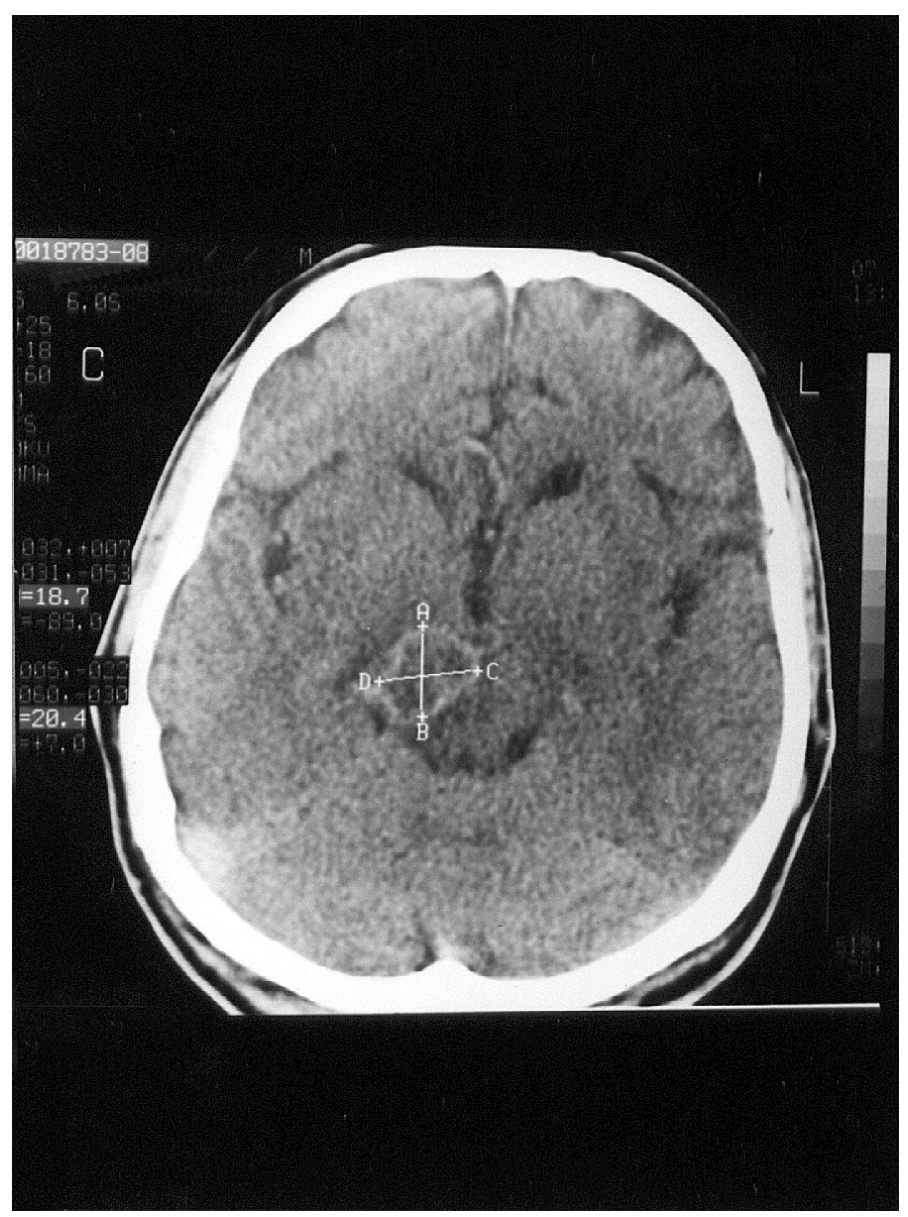

Fig. 2 - CT brain scan at the end of ITZ therapy. The edema has subsided, uptake of the contrast media is less intense although the lesion's size remains unaltered. 


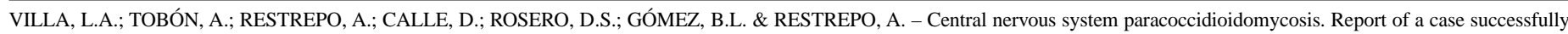
treated with itraconazol. Rev. Inst. Med. trop. S. Paulo, 42(4): 231-234, 2000.

The efficacy of ITZ in PCM, even in severe juvenile cases $^{12}$, as well as the known toxicity of amphotericin $\mathrm{B}^{4}$, led us to use ITZ at a dose twice the one generally employed ( $200 \mathrm{mg}$ /day). However, we initially disregarded the possible interaction with sodium valproate that resulted in lowered ITZ plasma levels due to their metabolism through the cytochrome P450 system ${ }^{5}$. Upon interruption of the latter drug and replacement by another anti-seizure medication, clinical response was achieved, and was accompanied by an important elevation of ITZ plasma levels and significant decreases in the titers of both circulating antigen and serum antibody.

Clinical response was noticed after two months with healing of the abdominal ulceration; intracraneal hypertension took a longer time (7 months) to resolve but improvement was gradual and marked. Although at the end of therapy hemiparesis was still present, the degree of impairment was minor. Previous reports do not mention the duration of the neurological sequelae and only one author ${ }^{18}$ refers to their persistence.

To the best of our knowledge, this is the first NPCM case that has been treated and responded to ITZ therapy. It is recommended that CNS involvement be considered in all patients with PCM in order to promptly establish both the diagnosis and the specific treatment, thus avoiding permanent brain damage and death of the patient.

\section{RESUMO}

\section{Paracoccidioidomicose do sistema nervoso central. Apresentação de um caso tratado com êxito com itraconazole}

A paracoccidioidomicose (PCM) é infecção pulmonar primária que algumas vezes pode se disseminar a outros órgãos e sistemas. $\mathrm{O}$ envolvimento do sistema nervoso central (SNC) é raro e devido ao fato que a alerta clínica e o estabelecimento do diagnóstico são tardios, a doença progride e o paciente piora. Aquí apresentamos caso de neuroparacoccidioidomicose (NPCM) observada em homem de 55 anos de idade que referia sintomas neurológicos (hemiparalisia esquerda, parestesias, ptose pálpebral direita, dor de cabeça, vômito e convulsões) de um mes de duração. Ao exame físico, foi achada lesão ulcerada e granulomatosa no abdômen. Como o diagnóstico era duvidoso, foi indicada biopsia estereotáxica; além disso provas micológicas a partir da lesão ulcerada e um lavado broncoalveolar foram realizados. Nas últimas amostras $P$. brasiliensis foi observado e depois a biopsia do cérebro revelou a presença do fungo. $\mathrm{O}$ tratamento com itraconazol foi iniciado mas a melhoria clínica não foi detectável; devido ao fato que o paciente estava tomando valproato de sódio para o controle das convulsôes, foi suspeita interação entre os dois medicamentos, que foi confirmada pela ausência do nível plasmático do antimicótico. Este último medicamento foi trocado por clonazepam e depois de algumas semanas a melhoria clínica foi percebida e acompanhada pela diminuição dos títulos de antígenos e anticorpos do $P$. brasiliensis. Em áreas endêmicas, o envolvimento do SNC deve ser considerado em doentes com PCM e a eficácia do itraconazole deve ser considerada.

\section{ACKNOWLEDGEMENTS}

The authors sincerely express their appreciation to Dr. Luz Elena Cano for providing assistance with the manuscript and to Dr. Myrtha Arango for her kind cooperation with the mycological analysis.

\section{REFERENCES}

1. AJELLO, L. - Paracoccidioidomycosis: a historical review. In: PAN AMERICAN SYMPOSIUM OF PARACOCCIDIOIDOMYCOSIS, 1., Washington, Pan American Health Organization, 1972. Proceedings. p. 3-10. (Sci. Publ. 254).

2. BARBOSA, W. \& VASCONCELOS, W.M.P. - Ação da sulfametoxazol associada ao trimetoprim na terapêutica da blastomicose sul-americana. Rev. Pat. trop., 2: 329$339,1973$.

3. BARRAVIERA, B.; MENDES, R.P.; MACHADO, J.M. et al. - Evaluation of treatment of paracoccidioidomycosis with cotrimazine (combination of sulfadiazine and trimetoprim). Preliminary report. Rev. Inst. Med. trop. S. Paulo, 31: 53-55, 1989.

4. BENNETT, J.E. - Antifungal agents. In: MANDELL, G.L.; BENNETT, J.E. \& DOLIN, R. Principles and practice of infectious diseases. 4. ed. New York, Churchill Livingstone, 1995. p. 2678-2682.

5. BRODEL, T.T. \& ELEWSIKI, B.E. - Clinical pearl: systemic antifungal drugs and interactions. J. Amer. Acad. Derm., 33: 259-260, 1995.

6. BRUMMER, E.; CASTAÑEDA, E. \& RESTREPO, A. - Paracoccidioidomycosis: an update. Clin. Microbiol. Rev., 6: 89-117, 1993.

7. COMO, J.A. \& DISMUKES, W.E. - Oral azole drugs as systemic antifungal therapy. New Engl. J. Med., 330: 263-272, 1994.

8. DE CASTRO, C.C.; YAMAGA, L.Y.I.; BERNARD, G.; SHIKANAI-YASUDA, M.A. \& CERRI, G.G. - MRI of central nervous system (CNS) paracoccidioidomycosis (PCM). In: ENCONTRO INTERNACIONAL SOBRE PARACOCCIDIOIDOMICOSE, 7, Campos do Jordão, 1999. Proceedings. p. 116.

9. DEL NEGRO, G.; MELO E ALBUQUERQUE, F.J. \& PIMENTA DE CAMPOS, E. Localização nervosa da blastomicose sul-americana. Rev. Hosp. Clin. Fac. Med. S. Paulo, 9: 64-80, 1954.

10. DUARTE, A.L.W.P.; BARUFFA, G.; TERRA, H.B.G. et al. - Paracoccidioidomicose sistêmica com envolvimento do sistema nervoso central. Rev. Soc. bras. Med. trop., 32: 439-442, 1999.

11. GOMEZ, B.L.; FIGUEROA, J.I.; HAMILTON, A.I. et al. - Antigenemia in patients with paracoccidioidomycosis: detection of the 87-kilodalton determinant during and after antifungal therapy. J. clin. Microbiol., 36: 3309-3316, 1998.

12. NARANJO, M.S; TRUJILlO, M.; MUNERA, M.I. et al. - Treatment of paracoccidioidomycosis with itraconazol. J. med. vet. Mycol., 28: 71-90, 1990.

13. NEGRONI, R. - Paracoccidioidomycosis (South American Blastomycosis, Lutz Mycosis). Int. J. Derm., 32: 847-859, 1993.

14. NOBREGA, J.P.S. \& SPINA-FRANÇA NETTO, A. - Neuroparacoccidioidomycosis In: FRANCO, M.; LACAZ, C.S.; RESTREPO, A. \& DEL NEGRO, G. Paracoccidioidomycosis. Boca Ratón, CRC Press, 1994. p. 321-330.

15. PEREIRA, W.C.; RAPHAEL, A. \& SALLUM, J. - Lesões neurológicas na blastomicose sul-americana. Estudo anátomo-patológico de 14 casos. Arq. Neuropsiquiatr., 23: 95-112, 1965.

16. PLA, M.P.; HARTUNG, C.; MENDOZA, P.; STUKANOFF, A. \& MORENO, M.J. Neuroparacoccidioidomycosis: case reports and review. Mycopathologia (Den Haag), 127: 139-144, 1994.

17. RODACKI, M.A.; DE TONI, G.; BORBA, L.A. \& OLIVEIRA, G.G. -Paracoccidioidomycosis of the central nervous system: CT findings. Neuroradiology, 37: 636-641, 1995.

18. SKACEL, M.; CARREGAL, E.; COSTA, R.L.B.; BORDY, F.B. \& VALLE, A.C.F. Comportamento do sistema nervoso central na paracoccidioidomicose. In: ENCONTRO INTERNACIONAL SOBRE PARACOCCIDIOIDOMICOSE, 7, Campos do Jordão, 1999. Proceedings. p. 110.

19. TORO, G. - Paracoccidioidomycosis. In: VINKEN, P.J.; BRUYN, G. \& KLAWANS, H.L. Handbook of clinical neurology. Amsterdam, Elsevier, 1988. p. 455-465.

20. VALLE, A.C.F.; SKACEL, M.; COSTA, R.L.B. et al. - A case report of intraspinal paracoccidioidomycosis. Rev. Inst. Med. trop. S Paulo, 40: 203-207, 1998.

Received: 19 January 2000

Accepted: 10 April 2000 